AGRO EKONOMI, Vol 29, Issue 2, December 2018, Page.173-184

DOI : http://doi.org/10.22146/ae.35044

ISSN 0215-8787 (print), ISSN 2541-1616 (online)

Available at https://jurnal.ugm.ac.id/jae/

\title{
THE INFLUENCE OF FISCAL POLICY ON AGRICULTURE SECTOR IN JAVA ISLAND
}

\section{Pengaruh Kebijakan Fiskal Terhadap Sektor Pertanian di Pulau Jawa}

\author{
Siti Sabrina Salqaura ${ }^{1}$, Jangkung Handoyo Mulyo ${ }^{2,3}$, \\ Dwidjono Hadi Darwanto ${ }^{2}$ \\ ${ }^{1}$ Student of Postgraduate Program of Faculty of Agriculture, Universitas Gadjah Mada \\ ${ }^{2}$ Department of Agricultural Socio-Economics, Faculty of Agriculture, \\ Universitas Gadjah Mada \\ Jl. Flora, Bulaksumur, Kec. Depok, Kabupaten Sleman, \\ Daerah Istimewa Yogyakarta, 55281 \\ ${ }_{3}$ Center for Population and Policy Studies (CPPS) Universitas Gadjah Mada \\ J1. Tevesia, Bulaksumur, Kec. Depok, Kabupaten Sleman, \\ Daerah Istimewa Yogyakarta 55281 \\ siti.sabrina.s@mail.ugm.ac.id
}

Submitted: 24 April 2018; Revised: 27 July 2018; Accepted: 21 September 2018

\begin{abstract}
One of government interventions to encourage the improvement of agriculture sector output is through fiscal policy in the form of government spending. Total government expenditure in provincial aggregate is used as government spending. The availability of fiscal decentralization policy provides an opportunity for the provincial government to manage the government expenditure allocation. This research aims to discover the influence of fiscal policy in Java by using the government expenditure variable and to find the influence of foreign investment, domestic investment and agricultural labor absorption toward GRDP of agriculture subsectors. This research used regression analysis of cross section SUR fixed effect panel data. The results indicate the total expenditure having significant positive effect towards GRDP of agriculture subsectors are the subsectors of food crops, plantation, livestock and fishery. Forestry subsector cannot be analyzed further because the error is not normally distributed. The absorption of labor in agriculture sector has significant negative effect towards plantation and livestock subsectors. The foreign investment has significant positive effect towards livestock subsector and domestic investment has negative significant influence towards GRDP of food crops subsector. The provincial government needs to support agriculture subsectors by allocating expenditure that will increase GRDP of agriculture subsectors and increasing foreign direct investment and domestic investment to agriculture subsectors.
\end{abstract}

Keywords: Agriculture Sector, Fiscal Policy, Government Expenditure, Panel Data

Salqaura, S.S, \&Mulyo, J.H. (2018). The Influence of Fiscal Policy on Agriculture Sector in Java Island. Agro Ekonomi. 29(2) : 173-184 


\section{INTISARI}

Salah satu intervensi pemerintah untuk mendorong peningkatan output sektor pertanian adalah melalui kebijakan fiskal berupa pengeluaran pemerintah. Pengeluaran pemerintah yang digunakan merupakan total pengeluaran pemerintah secara agregat provinsi. Adanya kebijakan desentralisasi fiskal memberikan kesempatan kepada pemerintah provinsi untuk mengatur alokasi pengeluaran pemerintah. Penelitian ini bertujuan untuk mengetahui pengaruh kebijakan fiskal di Pulau Jawa dengan menggunakan variabel total pengeluaran pemerintah dan mengetahui pengaruh penanaman modal asing, penanaman modal dalam negeri dan serapan tenaga kerja sektor pertanian terhadap PDRB sub-subsektor pertanian. Penelitian ini menggunakan analisis regresi data panel fixed effect cross section SUR. Hasil penelitian menunjukkan total pengeluaran berpengaruh positif signifikan terhadap PDRB sub-subsektor pertanian yaitu subsektor tanaman bahan makanan, perkebunan, peternakan, dan perikanan. PDRB kehutanan tidak dapat dianalisis karena error tidak terdistribusi normal. Serapan tenaga kerja sektor pertanian berpengaruh negatif signifikan terhadap subsektor perkebunan dan peternakan. Penanaman modal asing berpengaruh positif signifikan terhadap peternakan dan penanaman modal dalam negeri berpengaruh negatif terhadap PDRB subsektor tanaman bahan makanan. Pemerintah provinsi perlu mendukung subsektor pertanian dengan mengalokasikan pengeluaran yang akan meningkatkan PDRB subsektor pertanian dan meningkatkan investasi langsung asing dan investasi domestik ke subsektor pertanian.

Kata Kunci: Data Panel, Kebijakan Fiskal, Pengeluaran Pemerintah, Sektor Pertanian,

\section{INTRODUCTION}

Before the various developments of the latest technology existed, the agriculture sector was the earliest income source in a country. The agriculture sector is the trigger of industrial and service sectors. Currently, the highest income contributor comes from service sector followed by industry and agriculture sector. However, according to BPS (2017) (Central Bureau of Statistics), the number of Indonesian labor in various sectors in 2015 and 2016 are 114,819,199 and $118,411,973$ respectively. The biggest labor absorption was on agriculture sector with a total of labor absorption in 2016 up to $37,770,165$ people, followed by trading, restaurant and service sector of 26,689,630 people totally. Central Bureau of Statistics, in 2014, showed that the largest amount of rice field in the country is located in Java Island consisting of 3,248,394 ha or about $40.03 \%$ of Indonesia. It is important to understand that $57.48 \%$ of Indonesian population is living in this island. Java is also the biggest contributor by referring to the GRDP (using the 2000 constant price) in 2013 reaching at $1,637,075.82$ or $61.2 \%$. Thus, research focusing on agriculture sector in Java Island is important to be analyzed.

Shuaib et al., (2015) examined the impact of government spending on agriculture in Nigeria's economic growth from the year of 1960 to 2012. Shuaib et al., (2015) found that the government expenditures on agriculture has a direct 
correlation on the economic growth. Budiyanto et al., (2014) found that government spending on agriculture in 20 provinces in Indonesia from the year 2003 to 2011 has positive effect to investment, GRDP of agriculture, employment and negative effect to poverty rate. Ademola et al., (2013) also studied the contributions of agricultural sector and government expenditures towards national income in Nigeria from 1981 to 2010 , found that government expenditures has significant positive correlations with agriculture sector and economic growth in Nigeria. Izuchukwu (2011) conducted a research in Nigeria by using the data from the years of 1986 to 2007 . The research results showed that there is a positive correlation between GDP and the three estimated independent variables which are the domestic deposit, government expenditures on agriculture sector and direct foreign investment on agriculture sector. Oluwatoyese (2016) also conducted research in Nigeria regarding the factors of macro-economic that influence the agriculture output of Nigeria. There is a long term correlation between agriculture output and explanatory variables (commercial bank loan on agriculture, interest rate, inflation rate, exchange rate, foods import access, and unemployment rate).

The research of Rashid et al., (2016) used provincial panel data from 2003 to 2012. Pooled Ordinary Least Square
(POLS) in panel data model was used to estimate the factors influencing economy from FDI (Foreign Direct Investment) in agriculture. The result showed that there was a correlation between poverty and FDI in agricultural sector on some countries within Organization of the Islamic Cooperation (OIC) consisted of Malaysia, Oman, and Brunei. The same condition also occurred between the market size and FDI in agricultural sector. Siddiqui $\&$ Ahmed (2017) found that FDI does not have an impact on growth at the sectoral level (without agriculture) but growth has an impact on FDI. Kentor (1998) and Dixon \& Boswell (1996) cited by Almfraji \& Almsafir (2014) argues that foreign investment has an initial positive effect on growth but in the long term dependence on foreign investment has a negative effect on growth, as infrastructure and institutions developing with foreign investment support further foreign investment; and negative externalities such as unemployment, over-urbanization, and income inequality perpetuate problems.

Fiscal policy is a government policy concerning in the allocation of government spending and government revenues. One of its purposes to accelerate economic growth. Economic growth can be achieved by measuring the development of economic sectors. The components of fiscal policy are government expenditure and taxes. The agriculture sector contributes to the national 
economic growth both in the period when a country is still developing and has been developed due to increasing population followed by increasing food consumption. Recently, agriculture sector's contribution on GDP is declining. It is the third biggest contributor for national income after service and industry sector (lower than the previous years). This change is not followed by the decline in agricultural labor absorption. It occurs because the economic structure's transformation in becoming a developed country. The shift of economic sector is expected to occur without reducing the production within agriculture sector. However, agriculture sector shows slower development compared to other sectors. Along with the development of technology, the current governmental fiscal policy is centralized in the main economic sector to urge economic growth within the sector of service and industry instead of agriculture. This study attempts to discover whether fiscal policy through decentralization by using total government expenditure influence agriculture sector (using GRDP agriculture subsector) or not. The effect of fiscal policy involves government expenditure as the variable. The other objective is to discover the effect of agricultural labor absorption, foreign and local investment toward each agriculture subsectors such as food crops, plantation, livestock, fishery and forestry.

\section{METHODS}

The data used in this research was the annual data from 2001 to 2016 . The location of this research was chosen purposively in Java. Java was selected based on the data that showed the largest amount of rice field, labor absorption and the contribution to the national GDP. The research areas in this research were Banten, West Java, East Java, Central Java, and D.I. Yogyakarta Province. This research used panel data regression and analyzed using Eviews9 software. The data were collected from various publications published by Central Bureau of Statistics including the Province in Statistics for each province, the financial statistics of provincial government of catalog 7404, Indonesia statistics of catalog 1401, and the information was obtained from Central Bureau of Statistics' website.

The influence of fiscal policy can be directly observed through government expenditure. This formula is formed based on several past studies :

a. $\operatorname{LOG}($ PDRBSTBM $)=\alpha_{0}+$ $\alpha_{1}{ }^{*} \mathrm{LOG}(\mathrm{TEXP})+\alpha_{2}{ }^{*} \mathrm{LOG}(\mathrm{PTKSP})$ $+\alpha_{3} * \mathrm{LOG}(\mathrm{PMA})+\alpha_{4}{ }^{*} \mathrm{LOG}(\mathrm{PMDN})$ $+\mathrm{u}_{1}$. . .

The expected estimate sign $\alpha_{1}, \alpha_{2}, \alpha_{3}$, $\alpha_{4}>0$

b. LOG(PDRBSPKN) $=\beta_{0}+$ $\beta_{1}{ }^{*} \operatorname{LOG}\left(\right.$ TEXP) $+\beta_{2}{ }^{*}$ LOG(PTKSP) $+\beta_{3}{ }^{*} \mathrm{LOG}(\mathrm{PMA})+\beta 4 * \mathrm{LOG}(\mathrm{PMDN})$ $+u_{2} \ldots \ldots \ldots . . .(2)$ 
The expected estimate $\operatorname{sign} \beta_{1}, \beta_{2}, \beta_{3}$, $\beta_{4}>0$

c. LOG(PDRBSPT) $=\gamma_{0}+\gamma$ ${ }_{1}^{*} \mathrm{LOG}(\mathrm{TEXP})+\gamma_{2}{ }^{*} \mathrm{LOG}(\mathrm{PTKSP})$ $+\gamma_{3}{ }^{*} \mathrm{LOG}(\mathrm{PMA})+\gamma_{4}{ }^{*} \mathrm{LOG}(\mathrm{PMDN})$ $+\mathrm{u}_{3} \ldots \ldots \ldots \ldots \ldots . . .(3)$

The expected estimate sign $\gamma_{1}, \gamma_{2}, \gamma_{3,}$ $\gamma_{4}>0$

d. $\quad$ O O G ( P D R B S I K N $)=\delta_{0}+$ $\delta_{1}{ }^{*} \mathrm{LOG}(\mathrm{TEXP})+\delta_{2}{ }^{*} \mathrm{LOG}(\mathrm{PTKSP})$ $+\delta_{3}{ }^{*} \mathrm{LOG}(\mathrm{PMA})+\delta_{4}{ }^{*} \mathrm{LOG}(\mathrm{PMDN})$ $+\mathrm{u}_{4}$.

The expected estimate $\operatorname{sign} \delta_{1,} \delta_{2}, \delta_{3}$, $\delta_{4}>0$

e. $\mathrm{LOG}(\mathrm{PDRBSHTN})=\zeta_{0}+$ $\zeta_{1}{ }^{*} \mathrm{LOG}(\mathrm{TEXP})+\zeta_{2}{ }^{*} \mathrm{LOG}(\mathrm{PTKSP})+$ $\zeta_{3}{ }^{*} \operatorname{LOG}(\mathrm{PMA})+\zeta_{4}{ }^{*} \mathrm{LOG}(\mathrm{PMDN})+$ $\mathrm{u}_{5}$

The expected estimate $\operatorname{sign} \zeta_{1}, \zeta_{2}, \zeta_{3}, \zeta_{4}>$ 0

\section{Information:}

PDRBSHTN $=$ GRDP of Forestry Subsector (Million IDR)

PDRBSIKN = GRDP of Fishery Subsector (Million IDR)

PDRBSPKN $=$ GRDP of Plantation Subsector

(Million IDR)

PDRBSPT $=$ GRDP of Livestock Subsector (Million IDR)

PDRBSTBM= GRDP of Food Crops Subsector (Million IDR)

PMDN $=$ Domestic Investment (Million IDR)

PMA = Foreign Investment (Million Dollar)
PTKSP $=$ Labor Absorption of Agricultural sector (people)

TEXP $=$ Total Provincial Government Expenditures (Million IDR)

$\mathrm{u}=$ error

There are three tests should be conducted to determine the best model (Gujarati \& Porter, 2009):

\section{Chow Test}

Chow test is a test performed to discover whether the best model is fixed effect or common effect by using the $\mathrm{F}$ test.

The hypotheses used in this test are: $\mathrm{H}_{0}=\alpha_{1}=\alpha_{2}=\alpha_{\mathrm{i}}=0$ (Similar intercept, no significant effect from cross section unit) $\mathrm{H}_{1}=\alpha_{\mathrm{i}} \square 0 ; \mathrm{i}=1,2, \ldots, \mathrm{n}$ (at least one intercept with difference should be available, the significant effect from cross section unit is available)

$$
\text { If } \mathrm{F}_{\text {count }}>\mathrm{F}_{\alpha ; \mathrm{db} 1 ; \mathrm{db} 2} \text { or probability }
$$
value $<$ alpha $(10 \%, 5 \%$ or $1 \%)$ then $\mathrm{H}_{0}$ is rejected, it means that the model of fixed effect is better than common effect model.

\section{Breusch Pagan Test}

This test is used to discover the existence of random effect. It is done to compare whether the common effect or the random effect is the best model.

$\mathrm{H}_{\mathrm{O}}=\sigma_{u}^{2}=\mathrm{o}$

$\mathrm{H}_{1}=\sigma_{u}^{2} \neq \mathrm{o}$

If the probability value of $\mathrm{BP}<\alpha$ (1, 5 , and $10 \%$ ), then $\mathrm{H}_{0}$ is rejected or if the 
statistic value of $\mathrm{BP}>$ the critical statistic value of chi-squares, then $\mathrm{H}_{0}$ is rejected. It means that, estimation random effect model is better than common effect.

\section{Hausman Test}

Hausman test is applied to find out whether a random effect model or a fixed effect model is the best model. This test result shows the time component error with the series and cross section are correlates with any or all of the explanatory variables or not.

Hypotheses of Hausman test:

$\mathrm{H}_{\mathrm{O}}=$ Correlation $\left(\mathrm{X}_{\mathrm{it}} \mathrm{p}_{\mathrm{it}}\right)=0$; no cross sectional effect that correlated with the other independent variables, thus, the random effect model is better to used than fixed effect model.

$\mathrm{H}_{1}=$ Correlation $\left(\mathrm{X}_{\mathrm{it} \mathrm{P}_{\mathrm{i}}}\right) \neq 0$, cross sectional effect correlated with the other independent variables, thus, the fixed effect model is better to choose than random effect model. If the probability value of Hausman test lower than alpha 1,5 , and $10 \%$, it means that $\mathrm{H}_{0}$ is rejected so fixed effect model is the best model.

Another method to choose the best model is submitted by Fitrianto \& Musakkal (2016). The research showed the best model of panel data can be chosen based on Root Mean Square Error (RMSE) of the equation. MSE is a value that measures the average of the difference between the estimator and the actual data. The smallest RMSE value in statistics means that the best model estimated.

\section{RESULTS AND DISCUSSION}

Table 1 represents the results of chow test, BP LM test, and Hausman Test. Chow test $\mathrm{H}_{0}$ is rejected, it means that fixed effect model is better than common effect. Probability of (both) Breusch pagan LM test shows that all equation rejected $\mathrm{H}_{0}$. It means that the best model is random effect model. On the other hand, the probability of $\mathrm{X}^{2}$ in Hausman test indicates that $\mathrm{H}_{0}$ is rejected indicating that the best model is fixed effect.

Table 2 shows the result of RMSE of each function. Fixed effect model is applied because the smallest value of RMSE. Dependence test needs to be done to examine the correlation between cross section or not in residual. And then, table 3 shows that the four functions reject $\mathrm{H}_{0}$. It means that each function has correlation between cross section in residual. This research used cross SUR (Seemingly Unrelated Regressions) to estimate the function. Thus, the estimation is close to the actual condition. The last function (GRDP forestry) accept $\mathrm{H}_{0}$ meaning that there is no correlation between cross section in residual.

The normality test shows that the error of four functions (food crops, plantation, livestock and fishery) are normally distributed since the p-value is 
Table 1. The result of best model examination using various measurements

\begin{tabular}{|c|c|c|c|c|c|c|c|}
\hline \multirow[b]{2}{*}{ Function } & \multicolumn{2}{|c|}{ Chow Test } & \multicolumn{3}{|c|}{ Breusch Pagan LM Test } & \multirow{2}{*}{$\begin{array}{c}\text { Hausman } \\
\text { Test }\end{array}$} & \multirow[b]{2}{*}{ Summary } \\
\hline & $\begin{array}{c}\mathrm{F} \\
\text { (Prob.) }\end{array}$ & $\begin{array}{c}\mathrm{X}^{2} \\
\text { ( Prob.) }\end{array}$ & $\begin{array}{l}\text { Cross section } \\
\text { (Prob.) }\end{array}$ & $\begin{array}{l}\text { Time } \\
\text { (Prob.) }\end{array}$ & $\begin{array}{l}\text { Both } \\
\text { (Prob.) }\end{array}$ & & \\
\hline Food crops & $\begin{array}{l}332.04 * * * \\
(0.00)\end{array}$ & $\begin{array}{l}238.47 * * * \\
(0.000)\end{array}$ & $\begin{array}{l}372.37 * * * \\
(0.00)\end{array}$ & $2.64^{\text {ns }}(0.10)$ & $\begin{array}{l}375.02 * * * \\
(0.00)\end{array}$ & $\begin{array}{l}1328.19 * * * \\
(0.00)\end{array}$ & Fixed Effect \\
\hline Plantation & $\begin{array}{l}308.65^{* * *} \\
(0.00)\end{array}$ & $\begin{array}{l}232.93 * * * \\
(0.000)\end{array}$ & $\begin{array}{l}239.58 * * * \\
(0.00)\end{array}$ & $4.06 * *(0.04)$ & $\begin{array}{l}243.64 * * * \\
(0.00)\end{array}$ & $\begin{array}{l}1234.60 * * \\
(0.00)\end{array}$ & Fixed Effect \\
\hline Livestock & $\begin{array}{l}38.81 * * * \\
(0.00)\end{array}$ & $\begin{array}{l}92.71 * * * \\
(0.00)\end{array}$ & $\begin{array}{l}25.00 * * * \\
(0.00)\end{array}$ & $0.14^{\text {ns }}(0.70)$ & $\begin{array}{l}25.15^{* * * *} \\
(0.00)\end{array}$ & $\begin{array}{l}155.24 * * * \\
(0.00)\end{array}$ & Fixed Effect \\
\hline Fishery & $\begin{array}{l}166.76^{* * *} \\
(0.00)\end{array}$ & $\begin{array}{l}187.30^{* * *} \\
(0.00)\end{array}$ & $\begin{array}{l}167.91 * * * \\
(0.00)\end{array}$ & $0.95^{\text {ns }}(0.32)$ & $\begin{array}{l}168.87 * * * \\
(0.00)\end{array}$ & $\begin{array}{l}667.07 * * * \\
(0.00)\end{array}$ & Fixed Effect \\
\hline Forestry & $\begin{array}{l}155.27 * * * \\
(0.00)\end{array}$ & $\begin{array}{l}250.18 * * * \\
(0.00)\end{array}$ & $\begin{array}{l}83.57 * * * \\
(0.00)\end{array}$ & $1.24^{\text {ns }}(0.26)$ & $\begin{array}{l}84.81 * * * \\
(0.00)\end{array}$ & $\begin{array}{l}621.11 * * * \\
(0.00)\end{array}$ & Fixed Effect \\
\hline
\end{tabular}

Source : Secondary Data Analysis, 2018

Table 2. The result of RMSE

\begin{tabular}{lllll}
\hline \multirow{2}{*}{ Function (Subsector) } & \multicolumn{3}{c}{ Root Mean Square Error } & Summary \\
\cline { 2 - 4 } Food crops & Fixed Effect & Random Effect & Common Effect & \\
Plantation & 0.0451 & 0.2004 & 0.2004 & Fixed Effect \\
Livestock & 0.0839 & 0.3598 & 0.3598 & Fixed Effect \\
Fishery & 0.1000 & 0.1786 & 0.1786 & Fixed Effect \\
Forestry & 0.1160 & 0.3740 & 0.3740 & Fixed Effect \\
\hline
\end{tabular}

Source : Secondary Data Analysis, 2018

Table 3. The result of residual dependence test

\begin{tabular}{lrr}
\hline Function (Subsector) & Breusch-Pagan LM & Probability \\
Food crops & $20.8083^{* * *}$ & 0.0225 \\
Plantation & $28.9686^{* * *}$ & 0.0013 \\
Livestock & $85.7123^{* * *}$ & 0.0000 \\
Fishery & $75.2405^{* * *}$ & 0.0000 \\
\hline
\end{tabular}

Source : Secondary Data Analysis, 2018

higher than 0.05. Oppositely, forestry's function error is not normally distributed. Furthermore, the function cannot be analyzed. Multicolinearity test using the coefficient correlation shows that all functions reject multicolinearity as each independen variable value is below 0.8 . It indicates that independent variables are not correlated each other.
In order to find the influence of government expenditures in agriculture sector, the five uncorrelated structural equations are analyzed. The results were compiled in the table 4 and table 5 .
a. GRDP of Food Crops Subsector
Table 4 shows the estimation of total government expenditure is in accordance to 
the expected prediction. Total government expenditure has a significant positive effect to GRDP food crops subsector. An increase in total government expenditure including expenditure of goods and services will increase the production of goods and services (Abel et al., 2008). The subsectors that are positively influenced on the provincial government expenditures are also in accordance with the research done by Maria et al., (2008) showing that the effect of the regional autonomy implementation in Central Java Province which transform the region from underdeveloped into developed province. This estimation shows that total government expenditure in general including staff in various fields, infrastructure development will stimulate the output of food crops subsector indicated by the increase of GRDP food crops subsector. Based on the result, it shows domestic investment in Java will decline the output of food crops subsector. This result can occur because subsector which receive domestic investment the most is not food crops. Therefore, it will make output of the subsector receiving domestic investment increases. Also, because of another subsector obtains domestic investment, it shifts the input of food crops subsector such as labor and land. As a result, it will decrease the output of food crops subsector and GRDP of food crops subsector too.

In addition, variable $\mathrm{C}$ in table 4 is significant. It indicates that when total government expenditure, labor absorption of agriculture, foreign and domestic investment are zero, the GRDP of food crops subsector in Java will reach $1,557,355,891,747,11$ which is obtained from exponential of variable C. Table 5 shows that by arranging the variables of government total revenues, the absorption of agriculture labor, the foreign and domestic investments, provinces that have negative sign can increases GRDP food crops subsector.

\section{b. GRDP of Plantation Subsector}

The expected positive sign of total government expenditure matches with the estimation result. It means that government expenditure stimulates the growth of output in plantation subsector. However, the agricultural labor absorption does not achieve the expected sign. An increase of labor absorption should increase the output, but the estimation result shows that an increase in agricultural labor absorption will decrease the output of plantation. A research explaining about the negative sign between agricultural labor absorption and agricultural subsector is Julia \& Asmara (2015), the research mentioning it can happen because an increase of labor absorption will decrease the productivity of the subsector. Another research, Kurniasih (2017) mentions one of several factors which cause economic growth has insignificant negative effect on 
Table 4. The result of panel data regression

\begin{tabular}{|c|c|c|c|c|c|c|c|c|c|}
\hline \multirow{2}{*}{ Variabel } & \multirow{2}{*}{$\begin{array}{l}\text { Expected } \\
\text { Sign }\end{array}$} & \multicolumn{2}{|c|}{ Food Crops GRDP } & \multicolumn{2}{|c|}{ Plantation GRDP } & \multicolumn{2}{|c|}{ Livestock GRDP } & \multicolumn{2}{|c|}{ Fishery GRDP } \\
\hline & & Coefficient & Prob & Coefficient & Prob & Coefficient & Prob & Coefficient & Prob \\
\hline Constanta & & $14.2585^{* * *}$ & 0.0000 & $14.2081 * * *$ & 0.0000 & $12.7454 * * *$ & 0,0000 & $8.4578 * * *$ & 0.0000 \\
\hline $\begin{array}{c}\text { Total } \\
\text { Expenditure }\end{array}$ & + & $0.1447 * * *$ & 0.0000 & $0.1700 * * *$ & 0.0000 & $0.2397 * * *$ & 0,0000 & $0.3475 * * *$ & 0.0000 \\
\hline $\begin{array}{l}\text { Agricultural } \\
\text { Labor }\end{array}$ & + & $-0.0275^{\mathrm{ns}}$ & 0.4831 & $-0.2086 * * *$ & 0.0009 & $-0.1358 * *$ & 0,0183 & $-0.0295^{\text {ns }}$ & 0.7370 \\
\hline $\begin{array}{l}\text { Foreign } \\
\text { Investment }\end{array}$ & + & $0.0058^{\mathrm{ns}}$ & 0.1267 & $-0.0005^{\text {ns }}$ & 0.8830 & $0.0123 * *$ & 0,0138 & $0.0075^{\text {ns }}$ & 0.3283 \\
\hline $\begin{array}{l}\text { Domestic } \\
\text { Investment }\end{array}$ & + & $-0.0039 *$ & 0.0766 & $0.0007^{\mathrm{ns}}$ & 0.7925 & $-0.0009^{\text {ns }}$ & 0,8138 & $0.0019^{\text {ns }}$ & 0.5675 \\
\hline Adj $R^{2}$ & & \multicolumn{2}{|c|}{0.9997} & \multicolumn{2}{|c|}{0.9991} & \multicolumn{2}{|c|}{0.9969} & \multicolumn{2}{|c|}{0.9985} \\
\hline Prob. F stat. & & \multicolumn{2}{|c|}{0.0000} & \multicolumn{2}{|c|}{0.0000} & \multicolumn{2}{|c|}{0.0000} & \multicolumn{2}{|c|}{0.0000} \\
\hline
\end{tabular}

*** siginificant at $\alpha=0.01 ; * *$ significant at $\alpha=0.05, *$ significant at $\alpha=0.1,{ }^{\text {ns }}=$ nonsignificant Source : Secondary Data Analysis, 2018

Table 5. Cross section fixed effect value

\begin{tabular}{llcll}
\hline Province & Food Crops & Plantation & Livestock & Fishery \\
\hline Banten & -1.0402 & 0.3503 & -0.6517 & -0.3132 \\
Central Java & 0.6641 & -0.0650 & 0.4657 & 0.4667 \\
East Java & 0.8221 & 0.2214 & 1.0781 & 1.4500 \\
West Java & 0.8764 & -0.2266 & 0.6107 & 0.4729 \\
Yogyakarta & -1.3225 & -0.2802 & -1.5028 & -2.0766 \\
\hline
\end{tabular}

Source : Secondary Data Analysis, 2018

labor absorption is the primary sector with low productivity.

The regression result of plantation subsector shows that variable $\mathrm{C}$ is significant. In other words, when the total government expenditure, foreign and domestic investment, and the agricultural labor absorption value are constant or zero the GRDP of plantation subsector is $1,480,810,306,046.36$ IDR. The province's heterogeneity value means each province has different intercept due to the conditions of economic system, culture and other variables. Yogyakarta Province is the province with the weakest individual effect (-0.2802). It means when the government expenditures, the labor of agricultural sector, the foreign and domestic investments are having constant value or zero, it will have the lowest intercept while Banten Province will the highest intercept (0.3503). If we compare to the other subsectors, plantation subsector is the smallest heterogeneity between provinces and the difference in character of each province is not too extreme. It means that characteristics between provinces about plantation subsector are not too different. Province which has negative sign means that by arranging the variables, province can increase plantation subsector. 


\section{c. GRDP of Livestock Subsector}

The result shows that total expenditure government, and foreign investment has significant positive influence towards livestock subsector, whereas the absorption of agricultural labor has significant negative influence. An increase in foreign investment will increase the output of livestock subsector, it is supported by Newsletter Data Makro (2017), mentioning foreign direct investment of livestock subsector is concentrated in Java Island. Oppositely, an increase of agricultural labor absorption within livestock subsector will decrease the output of each subsector. Alexandi \& Marshafeni (2013) mentioned that agriculture sector does not absorb as much as service and mining sector because workers will be absorbed if the number of business units or employment is sufficient with the large number of workers available..

The estimation of livestock subsector regression has significant variable $\mathrm{C}$. It means that the minimum value of livestock subsector in Java is $342,970,597,191.52$ IDR when the values of total government expenditure, foreign and domestic investment and agricultural labor absorption are zero or constant. It means that the province government of Yogyakarta can arrange the variable to increase livestock subsector of Yogyakarta and so do the other provinces. d. GRDP of Fishery Subsector

The value of Variable $\mathrm{C}$ means that the minimum of fishery subsector is $4,711,680,889.04$ IDR when the other variables independence are zero or constant. The province's individual effect in the condition when the independent variables valued zero will result in the average intercept or general intercept to be added with the individual effect of each province. Government expenditure has positive significant effect towards fishery subsector, whereas the other variables independent are not significant.

When the government expenditure and the other independence variables are zero, then, the highest individual effect in producing the GRDP of fishery subsector is acquired by East Java (1.4500), while the lowest is acquired by Yogyakarta (-2.0766) or it can be defined as well that East Java has strong influence towards the GRDP of fishery subsector in Java. This result is in accordance with the total area of fishery cultivation in both the sea and freshwater, it shows that East Java is the largest area among the other provinces and the smallest is Yogyakarta.

\section{CONCLUSION AND SUGGESTION}

The total government expenditure has significant positive effect towards the GRDP of agriculture subsectors which are food crops, plantation, fishery and livestock. The agricultural labor absorption has significant negative effect towards the 
plantation and livestock subsectors. The foreign investment has significant positive effect towards livestock, and food crops subsector. At last, the agricultural labor absorption has a negative effect towards the plantation and livestock subsectors.

Based on the result, some provincial government have to provide more attention to some subsectors. Provincial government of Yogyakarta has to support the food crops, livestock, plantation and fishery subsectors. Likewise, provincial government of Banten has to support the food crops, livestock, and fishery subsectors, while West Java and Central Java government have to support plantation subsector. Such support is by allocating expenditures that will increase the agriculture subsectors and increase foreign direct investment and domestic investment to the agriculture subsectors. To find out the expenditure that significantly increases the subsectors, further research is needed.

\section{REFERENCES}

Abel, A. B., Bernanke, B. S., \& Croushore, D. (2008). Macroeconomics (Sixth Edit). Boston: Pearson Education Inc.

Ademola, I. S., Olaleye, S. O., Olusuyi, A. E., \& Edun, F. (2013). Government Expenditure on Agricultural Sector and Economic Growth in Nigeria ( 1981 2010 ). IOSR Journal of Humanities and Social Science, 8(4), 62-67.
Alexandi, M. F., \& Marshafeni, D. O. (2013). Penyerapan Tenaga Kerja Pada Sektor Pertanian dan Sektor Jasa Pasca Kebijakan Upah Minimum di Provinsi Banten. Jurnal Manajemen \& Agribisnis, 10(2), 71-80.

Almfraji, M. A., \& Almsafir, M. K. (2014). Foreign Direct Investment and Economic Growth Literature Review from 1994 to 2012. Procedia - Social and Behavioral Sciences, 129, 206-213.

Budiyanto, Priyarsono, D. S., Sinaga, B. M., \& Sudaryanto, T. (2014). The Impacts of Regional Government's Expenditures on the Agricultural Sector and Economic Performance in Indonesia. IOSR Journal of Economics and Finance (IOSR-JEF), 4(2), 33-40.

Fitrianto, A., \& Musakkal, N. F. K. (2016). Panel Data Analysis for Sabah Construction Industries: Choosing the Best Model. Procedia Economics and Finance, 35(October 2015), 241-248.

Gujarati, D. N., \& Porter, D. C. (2009). Basic Econometric Fifth Edition. New York: McGraw-Hill/Irwin.

Izuchukwu, O.-O. (2011). Analysis of the Contribution of Agricultural Sector on the Nigerian Economic Development. World Review of Business Research, l(1), 191-200. 
Julia, D., \& Asmara, A. (2015). Dampak

Kebijakan Fiskal terhadap Kinerja

Sektor Pertanian di Provinsi Riau.

Jurnal Dinamika Pertanian, 3(Desember), 233-248.

Kurniasih, E. P. (2017). Effect of Economic Growth on Income Inequality, Labor Absorption, and Welfare. Economic Journal of Emerging Markets, 9(October), 181-188.

Newsletter Data Makro. (2017). Subsektor Peternakan Triwulan 1 Tahun 2017, $7-9$.

Maria, Irham, \& Djuwari. (2008). Pertumbuhan dan Perubahan Struktur Sektor Pertanian Sebelum dan Setelah Otonomi Daerah. Agro Ekonomi, 15(1), $35-50$.

Oluwatoyese, O. P., Applanaidu, S. D. a/p, \& Razak, N.A.A. (2016). Macroeconomic Factors and Agricultural Sector in Nigeria. Procedia - Social and Behavioral Sciences, 219, 562-570.

Rashid, I. M. A., Bakar, N. A., \& Razak, N. A. A. (2016). Determinants of Foreign Direct Investment (FDI) in Agriculture Sector Based on Selected High-income Developing Economies in OIC Countries: An Empirical Study on the Provincial Panel Data by Using Stata, 2003-2012. Procedia Economics and Finance, 39(November 2015), 328-334.

Shuaib, I. M., Igbinosun, F. E., \& Ahmed, A. E. (2015). Impact of Government Agricultural Expenditure on the Growth of the Nigerian Economy. Asian Journal of Agricultural Extension, Economics \& Sociology, 6(1), 23-33.

Siddiqui, A. A., \& Ahmed, S. (2017). Impact of Foreign Direct Investment on Sectoral Growth of Indian Economy. International Journal of Economics and Financial Issues, 7(3), 29-31. 